\title{
Study on the Effect of CORE (Connecting, Organizing, Reflecting and Extending) Learning Model on Mathematics Learning Outcomes of Cognitive Domain
}

\author{
Tiya Syahtriya Ningsih ${ }^{1, *}$, Abdurahman², Djemari Mardapi ${ }^{3}$, Suritno Fayanto $^{4}$ \\ ${ }^{1}$ Department of Master in Educational Research and Evaluation, Yogyakarta State University, Indonesia \\ ${ }^{2}$ Department of Mathematic Education, Islamic University of Riau, Indonesia \\ ${ }^{3}$ Department of Educational Research and Evaluation, Yogyakarta State University, Indonesia \\ ${ }^{4}$ Department of Master in Physics Education, Ahmad Dahlan University, Indonesia
}

Received July 31, 2019; Revised October 14, 2019; Accepted October 24, 2019

Copyright $\odot 2019$ by authors, all rights reserved. Authors agree that this article remains permanently open access under the terms of the Creative Commons Attribution License 4.0 International License

\begin{abstract}
In the world, mathematics education is one of the fields of study that occupies an important role in creating students who think logically, rational, critical and insightful. Therefore, mathematics is indispensable everyday life and a provision in the face progress of science and technology. This study aimed to assess the effect of the learning model CORE towards mathematics learning outcomes, especially those in the cognitive aspects - this research conducted at Junior High School 34 Pekanbaru with a quasi-experimental type of research. The study design uses a nonequivalent control group design with a sample of all students in class vii-1 (control class) and class vii-2 (experiment class). Data collection techniques using test techniques, observation techniques, and documentation techniques. While the data collection instruments used were a test sheet and observation sheet. Student learning outcomes tests were analyzed using descriptive statistical data analysis and inferential statistical data analysis. Results of data analysis descriptive study gained an average of learning outcomes posttest experimental classes $(\mathrm{VII}-2)=83.70$, and grade control $(\mathrm{VII}-1)=68.02$, whereas the results of t-test analysis showed that the experimental class (VII-2) is higher than the control classes (VII-1) seen from the values that $t_{\text {count }}$ $(3,81)>t_{\text {table }}(68,02)$ with significance level $\alpha=0,05$. So it was concluded that the CORE model influences mathematics learning outcomes, especially on cognitive aspects.
\end{abstract}

Keywords Education, CORE Model, Learning Outcomes, Mathematics Learning Outcomes, Mathematics Leaming

\section{Introduction}

Mathematics is a science that plays an essential role in preparing quality human resources and has character and competent in the development of science and technology. In line with the importance of a building civilization through education imbued with the nation's noble values. When someone studies mathematics, they are practising the character of thinking ability which not only involves the construction of ideas and concepts, but also the application of abstraction that he learned of the mathematical sciences [1]. In mathematics, the problem-solving ability of Indonesian students is still low compared to other countries. One of the benchmarks is the results of a survey from Trends in Mathematics and Science Study (TIMSS), which is conducted every four-year since 1995. During the survey, Indonesia always gets an average score below the international average of 500 [2]. The TIMSS survey results are presented in the following Table 1:

Table 1. Indonesia's position on the TIMSS survey

\begin{tabular}{|c|c|c|}
\hline Year & Score & Rank \\
\hline 2011 & 386 & 38 \\
\hline 2017 & 397 & 36 \\
\hline
\end{tabular}

Based on Table 1, it shows that Indonesia is at rank 38 (2011) and rank 36 (2017) from a total of 49 countries. Conditions were not much different seen from the results of studies conducted PISA (Program for International Student Assessment) in 2009, Indonesia was ranked 61 out of 65 countries with an average score of 371 with an average score of International 500. Meanwhile, in 2012, Indonesia was ranked 64th out of 65 countries with an average score 
of 375 , while the International average score is 500 . Whereas in 2015, Indonesia is ranked 69th out of 76 countries (Ministry of Education and Culture, 2015). The survey results above explain the importance of improving mathematics learning outcomes in students both nationally and internationally by making changes to the learning process and using more learning models in teaching. This raises concerns, especially in learning mathematics in Indonesia.

The main problem is the understanding of concepts possessed by students, because understanding concepts and problem-solving are very closely related. So students can understand the concept, but he is weak in finding ideas to solve problems, or vice versa, he has an idea to solve a problem, but the concept of understanding is lacking, or even both are lacking [3]. Other than that, lessons in our education system (Indonesia) so far are more often taught partially, stand-alone lessons as if separate from other lessons. Besides, the material in learning mathematics is also more on learning theoretical concepts and paying less attention to the meaning of applications in everyday life [1]. So students who study mathematics feel that the knowledge they are learning is less meaningful or even considered useless in their lives. Another problem is the low ability students' mathematical connection can be due to factors ability of teachers to provide learning of mathematics, or the ability of teachers to use instructional media of mathematics that have an impact on student learning outcomes. This expression amplified from surveys and interviews in one town in the province of Riau (Indonesia).

The survey showed that in the Riau province of average values for lesson Matermatika UN decline. In the academic year 2014/2015, the average junior high school mathematics UN score in Riau is 62.18 , whereas in the 2015/2016 school year the average junior high school mathematics UN scores in Riau decreased to 58.57 (Ministry of Education and Culture, 2016). As for junior Pekanbaru still ranked highest on average outperformed the 11 districts/cities in Riau with an average value of 306.30. While for Junior High Schoo of Pekanbaru, it still ranks highest in average outperforming 11 districts/cities in Riau with an average value of 306.30 . Based on these facts, the learning outcomes of junior high school students in Riau need to get dangerous handling.

Furthermore, learning activities in schools are still dominated by educators, so students are less actively involved in learning [4], [5]. It reinforced by [6] that there are still many school students in learning mathematics who have difficulty in understanding a concept, doing mathematical proof, deducing mathematical statements, solving mathematical problems, especially mastering the ability to think critically mathematically. The same thing is in line with the findings of [7] that the condition found in the field is that many students still experience difficulties when finding questions that are different from the example even though it is still in the same mathematical concept.
The condition is very ironic to see that there are still many students who have difficulty connecting the material learned with the prerequisite material that has been taught before, concepts that have been taught not last long so that the connection of mathematics students is still low. It appeared at the time of the learning takes place, learners feel embarrassed and afraid to ask the subject matter that they don't understand. It is evident from the results of student work not being able to do well, and there are still many students who procrastinate doing assignments from educators [8].

To overcome these problems, it required appropriate learning models to facilitate learners to enhance the learning intentions further. One learning model that can encourage students is the Connecting, Organizing, Reflecting and Extending (CORE) learning model. The CORE learning model adopted by Calfee et al., which consists of four aspects: First, discussion determines connections to learning; second, discussion helps organize knowledge; third, a proper discussion can enhance reflective thinking; and the fourth, discussion helps broaden student knowledge [9]. At CORE Learning emphasizes the students' thinking ability to connect, organize, deepen, manage and develop information obtained [10].

Students are required to be able to think critically about the information he gets. In activities connecting the old and new concepts, students are trained to remember old information and use old information or concepts used in new information or concepts. The teacher is only as a facilitator, motivator and mediator. These elements are used to connect the old information with new information, organize a variety of materials, reflect on all the things that students learn and develop the learning environment [11], [12]. The results of research by [2] state that the CORE learning model (Connecting, Organizing, Reflecting, Extending) can help in improving mathematical connection skills. Besides that [13] stated that the CORE model had a positive relationship in developing mathematical skills. Similar research results come from [9] who explain that CORE emphasizes students to be able to build their knowledge by connecting and organizing new knowledge and old knowledge, thinking about the study of the concept (reflecting) and broadening their knowledge during the teaching-learning process (expanding). Furthermore, [14] suggested that using CORE models can improve learning outcomes in mathematics.

In this study, researchers focused on cognitive learning outcomes in mathematics; it based because the cognitive domain consists of several aspects: knowledge, comprehension, application, analysis, synthesis and evaluation. Besides looking at the reviews gap between learning mathematics is supposed to do with the reality on the ground is very different, which resulted in the still low student mathematics learning outcomes. To solve these problems, researchers are interested in studying the effect 
of the CORE learning model on mathematics learning outcomes, especially on the cognitive aspects of students. The aim is to provide information and descriptions of the use of CORE models in learning mathematics in schools, especially at the level of Junior High School as well as contribute to the development of learning models in Indonesia.

\section{Materials and Methods}

\subsection{Types of Research and Research Variables}

This type of research is a quasi-experimental with independent variables is the learning model CORE (Connecting, Organizing, Reflecting, and Extending) and the dependent variable is the learning outcomes of the cognitive domain of mathematics in class VII Junior High School of 34 Pekanbaru. The location of the study was at Junior High School of 34 Pekanbaru Riau Indonesia

\subsection{Population and Sample}

The population of this study was all students of class VII amounting to 267 people, spread over seven classes with different mathematics subject teachers. The data class VII Junior High School of 34 Pekanbaru 2016/2017 academic year can be seen in Table 2 below:

Table 2. The population of students in class VIII Junior High School 34 Pekanbaru

\begin{tabular}{|c|c|c|c|}
\hline Class & Man & women & number of students \\
\hline VII-1 & 20 people & 18 people & 38 \\
\hline VII-2 & 22 people & 16 people & 38 \\
\hline VII-3 & 20 people & 19 people & 39 \\
\hline VII-4 & 17 people & 21 people & 38 \\
\hline VII-5 & 19 people & 20 people & 39 \\
\hline VII-6 & 19 people & 19 people & 38 \\
\hline VII-7 & 18 people & 21 people & 39 \\
\hline
\end{tabular}

In this study, researchers used a simple random sampling or better known as a random sample. The research sample is shown in Table 3

Table 3. Research sample

\begin{tabular}{|c|c|c|c|c|c|}
\hline Class & Model & Class & Man & Woman & $\begin{array}{c}\mathrm{a} \\
\text { number }\end{array}$ \\
\hline Experiment & CORE & VII-2 & 22 & 16 & 38 \\
\hline Control & Conventional & VII-1 & 20 & 18 & 38 \\
\hline
\end{tabular}

\subsection{Desain Penelitian}

The design used in this study is the Nonequivalent Control Group Design. The research design described as follows:

\begin{tabular}{|c|c|c|c|}
\hline Class & Pretest & Treatment & Posttest \\
\hline experiment & $\mathrm{O}_{1 \mathrm{e}}$ & $\mathrm{X}$ & $\mathrm{O}_{2 \mathrm{e}}$ \\
\hline control & $\mathrm{O}_{1 \mathrm{k}}$ & - & $\mathrm{O}_{2 \mathrm{k}}$ \\
\hline
\end{tabular}

Where,

$\mathrm{O}_{1 \mathrm{e}}=$ Experiment class pretest

$\mathrm{O}_{2 \mathrm{e}}=$ Experiment class posttest

$\mathrm{X}=$ Given CORE Learning Model treatment

$-=$ Given the treatment of conventional learning models

$\mathrm{O}_{1 \mathrm{k}}=$ Pretest control class

$\mathrm{O}_{2 \mathrm{k}}=$ Posttest control class

\subsection{Learning Tools}

Learning tools consist of Syllabus, Learning Program Plan, Student worksheet

\subsection{Data Collection Techniques}

Data collection techniques consist of test techniques, observation techniques, documentation techniques. Data collection instruments consist of a test sheet covering (validity, reliability, different item, about the difficulty index) and the observation sheet.

\subsection{Data Analysis Techniques}

The data analysis technique consists of descriptive analysis (calculates the average value) and inferential analysis (normality test, homogeneity). Assisted data analysis using SPSS software and Microsoft EXCEL in 2010. To test the hypothesis using T-test which involves a series of:

1) Test the equality of two average value of pretest (test two parties)

Hypothesis for pretest:

$\mathrm{H}_{0}: \mu 1=\mu 2$ : The average results of students' mathematics learning experimental class are equal to the average student learning outcomes control class

$\mathrm{H}_{1}: \mu 1 \neq \mu 2$ : The average mathematics learning outcomes between students of the experimental class are different from those of the control class students before being given different treatments.

2) Test the equality of two average pretest score (Test of the parties)

Hypothesis for posttest:

$\mathrm{H}_{0}: \mu_{1}=\mu_{2}$ : The average results of mathematical learning between classes using model CORE equal to the average classroom using conventional teaching. It means that there is no average impact of the learning outcomes of learning mathematics that uses models CORE.

$\mathrm{H}_{1}: \mu_{1}>\mu_{2}$ : The average results of mathematical learning between classes using CORE learning model is better than the average of the class using conventional learning. It means that there is a common effect of learning outcomes 
in mathematics using the CORE learning model.

\section{Result}

\subsection{Description of the Implementation of Learning}

This research was conducted in class VII-1 and VII-2 Junior high school of 34 Pekanbaru, as many as six meetings in the experimental class and six meetings in the control class. The first meeting the researcher took the pretest data, which is to give an initial test before treatment. This pretest is to find out the homogeneity of both classes both the experimental class and the control class. The second meeting to the fourth meeting is the implementation stage of treatment using the CORE learning model in class VII-2, namely as an experimental class. While the second meeting until the fourth meeting of the implementation phase without treatment using conventional learning models in class VII-1 is a control class. Furthermore, the sixth meeting of the posttest done in class VII-1 and VII-2. Posttest is an assessment conducted after the learning process. Data posttest results were analyzed and then used as a benchmark to determine whether or not there is a learning model CORE influence on the results of the cognitive learning mathematics class VII Junior High School of 34 Pekanbaru. Learning implementation outlined in Table 4.

Table 4. Description of the implementation of learning

\begin{tabular}{|c|c|c|}
\hline Implementation of the CORE Learning Model & Impact on Student Activity & Interpretation \\
\hline $\begin{array}{l}\text { At the second meeting, with learning material about the understanding, } \\
\text { types, and properties of triangles guided by Lesson Plan -1. The teacher } \\
\text { enters the class on time and greets, there are no students, and the teacher } \\
\text { prays together, only gives a greeting led by the chairman because the } \\
\text { learning process is the fifth and sixth hours, 16: 16-17: } 30 \text { WIB. The } \\
\text { learning process only lasts } 2 \times 30 \text { minutes out of } 2 \times 40 \text { minutes not as } \\
\text { scheduled, because students hold the Asr prayer in congregation. Then the } \\
\text { teacher absences the student and asks who is absent; it known that two } \\
\text { students are absent. The teacher writes the material to be learned then } \\
\text { conveys the learning objectives and motivates students by telling them } \\
\text { about the benefits of knowing the meaning of a triangle. Teachers deliver } \\
\text { material prerequisites of lines and angles and associate with the material } \\
\text { to be studied. Next, the learning that will be carried out is learning using } \\
\text { the CORE model during the learning process, which runs from the second } \\
\text { meeting to the sixth meeting that will hold group study determined by the } \\
\text { researcher. Then in the core activities, students discuss with their } \\
\text { respective groups, discuss student worksheets, work together and share } \\
\text { ideas they get in completing worksheets (organizing). Students do not } \\
\text { complete student worksheet-1 entirely and do not present the results of the } \\
\text { discussion (reflecting), so the teacher does not correct the results written } \\
\text { by students if there are errors due to insufficient time. Student } \\
\text { worksheet-1 and the training contained in student worksheet-1 } \\
\text { individually (extending) are made homework to strengthen their } \\
\text { understanding of the material. At the end of class time, students with the } \\
\text { guidance of the teacher conclude the material and provide homework } \\
\text { questions while delivering the material to be studied next. }\end{array}$ & $\begin{array}{l}\text { Students have not been seen active in the } \\
\text { learning process, because it is still } \\
\text { adapting to the model used, then students } \\
\text { need much time to do worksheets } \\
\text { because during the learning process only } \\
\text { takes } 2 \times 30 \text { minutes from the scheduled } \\
\text { schedule, so students have not been able } \\
\text { to expand the material by doing } \\
\text { individual assignments. }\end{array}$ & $\begin{array}{l}\text { The CORE } \\
\text { learning model } \\
\text { has not been able } \\
\text { to influence } \\
\text { student learning } \\
\text { activities at this } \\
\text { first meeting. }\end{array}$ \\
\hline $\begin{array}{l}\text { At the third meeting with the material, one of the triangles' large angles } \\
\text { and the long side relationship of the triangle is guided by Lesson plan-2. } \\
\text { The learning activities are the same as the learning activities of the } \\
\text { previous meeting. Student activities are discussions in working on Student } \\
\text { Worksheet- } 2 \text { and seen each member working together in conducting } \\
\text { discussions, but some students do not cooperate with their friends. When } \\
\text { discussion researchers as instructors feel overwhelmed to respond to } \\
\text { group questions on the material they do not understand, then when the } \\
\text { learning process students have begun to be active, thus making the } \\
\text { atmosphere a little noisy. But the learning process runs smoothly and the } \\
\text { teacher can give awards to groups who present the results of the } \\
\text { discussion. Furthermore, students have begun to dare to present the results } \\
\text { of their discussions and while working on the Student Worksheet students } \\
\text { have begun to understand the steps of the CORE in the Student Worksheet } \\
2 \text {, then students organize their ideas in the Student Worksheet } 2 \text {, then do } \\
\text { the exercises on Student Worksheet } 2 \text {. }\end{array}$ & $\begin{array}{l}\text { Students have begun to look active, } \\
\text { although only a few and begin to know a } \\
\text { little about the model used. Then the time } \\
\text { used is sufficient and does not require } \\
\text { much time, so students can work on the } \\
\text { steps contained in the worksheet such as } \\
\text { connecting new experiences with old } \\
\text { experiences, organizing ideas in the } \\
\text { material, then explore the information } \\
\text { obtained in group learning and can } \\
\text { expand the material by doing the } \\
\text { exercises. }\end{array}$ & $\begin{array}{l}\text { The learning } \\
\text { model has begun } \\
\text { to affect the } \\
\text { students in } \\
\text { learning } \\
\text { activities. }\end{array}$ \\
\hline $\begin{array}{l}\text { At the fourth meeting with the material around and the area of the triangle } \\
\text { guided by Lesson plan - } 3 \text {, Learning activities are still the same as previous } \\
\text { learning activities. At this meeting, many students asked questions, and } \\
\text { the learning process went smoothly. Students play an active role in } \\
\text { completing student worksheet-3 then participate in completing the results }\end{array}$ & $\begin{array}{l}\text { Students are actively involved in } \\
\text { learning, does not require much time } \\
\text { because the material is small; students } \\
\text { have gained learning experiences; } \\
\text { students can carry out CORE steps. }\end{array}$ & $\begin{array}{l}\text { The CORE } \\
\text { learning model } \\
\text { has influenced } \\
\text { student activity } \\
\text { in learning. }\end{array}$ \\
\hline
\end{tabular}




\begin{tabular}{|c|c|c|}
\hline $\begin{array}{l}\text { of the discussion. Furthermore, there is enough learning time for students } \\
\text { to work on student worksheet- } 3 \text { and core steps in student worksheet-3, } \\
\text { likewise, with the workings of individual exercises that run to provide a } \\
\text { learning experience for students. }\end{array}$ & & \\
\hline $\begin{array}{l}\text { In the fifth meeting with the material to solve problems related to the } \\
\text { triangle guided by Lesson plan }-4 \text {. The fifth meeting is supposed to hold } \\
\text { on Thursday, March 23, 2017, because field study teachers use the } \\
\text { learning process time for MID semester. The learning activities at this } \\
\text { fifth meeting have been going very smoothly, and each group has an } \\
\text { active role in the learning process and in completing student worksheet-4, }\end{array}$ & $\begin{array}{l}\text { Students are actively involved in } \\
\text { learning, do not require much time } \\
\text { because the material is small; students } \\
\text { have gained learning experiences; } \\
\text { students can carry out CORE steps. }\end{array}$ & $\begin{array}{l}\text { The CORE } \\
\text { Learning Model } \\
\text { has influenced } \\
\text { student activities } \\
\text { in learning. }\end{array}$ \\
\hline
\end{tabular}

The core learning model is useful for connecting and constructing acquired understandings. CORE models students are required to be able to build competencies and understandings obtained from a variety of literature and pour in an idea or a problem-solving. Following are the activities of students and teachers during the learning process.

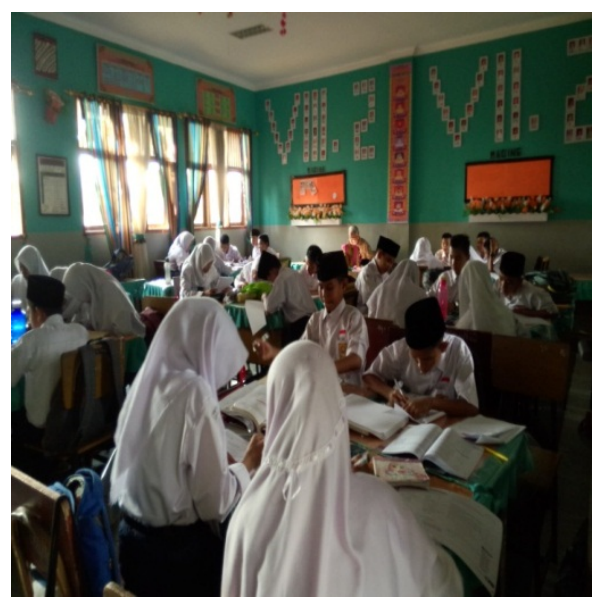

Figure 1. Students conduct discussions related to the material provided by the teacher

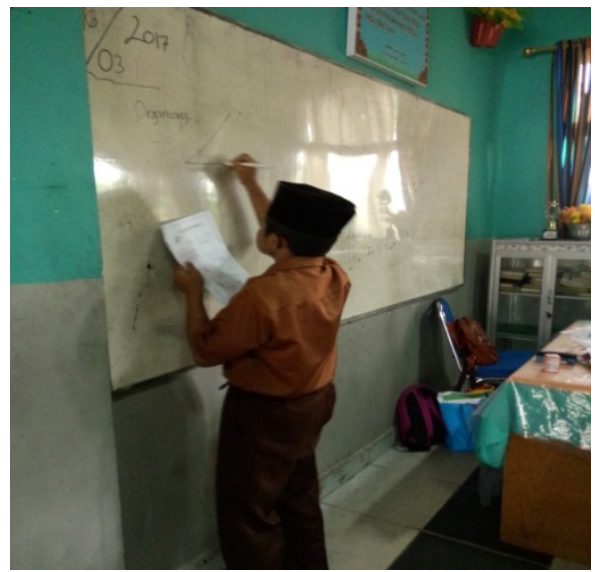

Figure 2. Students present the results of the discussion

\subsection{Descriptive Analysis}

From the pretest and posttest data that have realised in both classes, can be analyzed descriptively as in Table 5 below:
Table 5. Experimental and Control Class Pretest and Posttest Result Data

\begin{tabular}{|c|c|c|c|c|}
\hline \multirow{2}{*}{$\begin{array}{c}\text { Descriptive } \\
\text { Analysis }\end{array}$} & \multicolumn{2}{|c|}{ Pretest } & \multicolumn{2}{c|}{ Posttest } \\
\cline { 2 - 5 } & Experiment & Control & Experiment & Control \\
\hline $\begin{array}{c}\text { Number of } \\
\text { Samples (n) }\end{array}$ & 37 & 37 & 37 & 37 \\
\hline $\begin{array}{c}\text { Minimum } \\
\text { Value }\end{array}$ & 20 & 40 & 55 & 38 \\
\hline $\begin{array}{c}\text { Maximum } \\
\text { Value }\end{array}$ & 90 & 80 & 100 & 100 \\
\hline Average $(\bar{x})$ & 52.95 & 53.54 & 83.70 & 68.02 \\
\hline $\begin{array}{c}\text { Standard } \\
\text { Deviation }\end{array}$ & 15.42 & 10.97 & 12.50 & 20.74 \\
\hline
\end{tabular}

Based on Table 5, it can be seen that on average, the pretest results of the experimental class are not much different from the control class. However, after being given treatment in the experimental class, the average results of posttest of posttest results was far different from the control class. It explains that in the experimental class treated with the CORE learning model, there is a change in grades that is better than the control class using conventional learning models. Then to see whether or not there is an influence of the CORE learning model on the learning outcomes of the experimental class and the control class, an inferential analysis performed.

\subsection{Inferential Analysis}

The data analysis technique used in this study is the t-test. The t-test is one of the statistical tests used to determine the presence or absence of significant influence before treatment is given, namely the test of the similarity of two averages for the pretest value (two-party test) and the test of the difference of two averages posttest value (one-party test).

1) Homogeneity Test Results of Experimental Class Values (VII-2) and Control Class (VII-1)

Homogeneity variance test is performed to determine whether the experimental class and the control class have the same diversity (variance) or not before getting a different treatment. In determining whether the two variances are the same or not is done by using a comparison between the $F_{\text {count }}$ and $F_{\text {table }}$ tests. I have obtained by comparing the value of the most significant variance with the smallest variance value - the results of the homogeneity test analysis of the pretest values presented in Table 6 . 
Table 6. Homogeneity Test of Pretest Value of Experiment Class and Control Class

\begin{tabular}{|c|c|c|c|c|c|c|}
\hline Class & Variance & $N$ & $F_{\text {count }}$ & $F_{\text {table }}$ & Information & Conclusion \\
\hline Experiment & 261.15 & 38 & \multirow{2}{*}{2.31} & \multirow{2}{*}{1.72} & $\mathrm{~F}_{\text {count }} \geq \mathrm{F}_{\text {table }}$ & $\mathrm{H}_{0}$ rejected \\
\hline Control & 113.21 & 38 & & & & \\
\hline
\end{tabular}

Based on Table 6, it can be observed that the value of $F_{\text {count }}=2.31 \geq F_{\text {table }}=1.72$, it can be concluded that $\mathrm{H}_{0}$ is rejected. It means that both the experimental class and the control class have non-homogeneous variances.

2) Similarity Test Results of Two Average Pretest Values of Experimental Class (VII-2) and Control Class (VII-1)

Because the two classes namely the experimental class and the control class are not homogeneous, then the next of test the difference of two averages (t-test) to determine the comparison of fundamental knowledge before given different treatment between the experimental class with the control class. The results of the two average similarity test can be seen in Table 7 as follows:

Table 7. Average and Variance Values of Pretest for Experiment and Control Class

\begin{tabular}{|c|c|c|c|c|c|c|}
\hline Class & $\mathrm{n}$ & $\bar{x}$ & $\mathrm{~S}_{\text {combined }}$ & $t_{\text {count }}^{\prime}$ & $t_{\text {table }}^{\prime}$ & Information \\
\hline Experiment & 38 & 52,95 & \multirow{2}{*}{13,68} & $-0,18$ & 2,02 & $\mathrm{H}_{0}$ be accepted \\
\hline Control & 38 & 53,54 & & \\
\hline
\end{tabular}

Based on the average and variance of the experimental class and the control class (Table 7), then obtained $t^{\prime}$ count $=-0.18$ and $t_{\text {table }}^{\prime}=2.02$, then $\mathrm{H}_{0}$ is accepted. Means there is no difference in the average learning outcomes of students in the experimental class and the control class.

3) Homogeneity Test Results of Posttest Values of Experimental Class (VII-2) and Control Class (VII-1)

Homogeneity change test is performed to find out whether the experimental and control class were homogeneous or non-homogeneous after getting different treatments. To determine whether the two variances are the same or not, a comparison between $\mathrm{F}_{\text {count }}$ and $\mathrm{F}_{\text {table }}$ tests performed. $\mathrm{F}_{\text {count }}$ obtained by comparing the value of the most significant variance with the value of the smallest variance. Calculation results can be seen in Table 8 .

Table 8. Homogeneity Test Posttest Value Experiment Class and Control Class

\begin{tabular}{|c|c|c|c|c|c|c|}
\hline Class & Variance & $\mathrm{N}$ & $\mathrm{F}_{\text {count }}$ & $\mathrm{F}_{\text {table }}$ & Information & Conclusion \\
\hline Experiment & 174.77 & 38 & \multirow{2}{*}{2.59} & \multirow{2}{*}{1.72} & \multirow{2}{*}{$\mathrm{F}_{\text {count }} \geq \mathrm{F}_{\text {table }}$} & $\mathrm{H}_{0}$ rejected \\
\hline Control & 452.84 & 38 & & & \\
\hline
\end{tabular}

Based on Table 8. above, it can be observed that the value of $\mathrm{F}_{\text {count }}=2.59 \geq \mathrm{F}_{\text {table }}=1.72$, so we get the conclusion that $\mathrm{H}_{0}$ is rejected. It means that both the experimental class and the control class have non-homogeneous variances.

4) Difference Test Results of Two Experiment Posttest Values (VII-2) and Control Class (VII-1)

Because the two classes namely the experimental and control class are not homogeneous, then the next of the difference of two averages (T-test). T-test was conducted to determine whether there is an influence of the CORE learning model on mathematics learning outcomes. The results of the two different test averages can be seen in Table 9 as follows.

Table 9. Average and Variance Values of Experimental Class and Control Class Posttest

\begin{tabular}{|c|c|c|c|c|c|c|}
\hline Kelas & $\mathrm{n}$ & $\bar{x}$ & $\mathrm{~S}_{\text {combined }}$ & $t_{\text {count }}^{\prime}$ & $t_{\text {'table }}$ & Information \\
\hline Experiment & 38 & 83,70 & \multirow{2}{*}{17,71} & 3,81 & 1,68 & $H_{0}$ rejected \\
\hline Control & 38 & 68,02 & & & \\
\hline
\end{tabular}

Based on the average and variance (Table 9) of the experimental class and the control class, then obtained $t_{\text {count }}^{\prime}=3.81$ $>t_{\text {table }}^{\prime}=1.68$, then obtained $\mathrm{H}_{0}$ is rejected. Means the average learning outcomes of mathematics between classes using the CORE model is better than the average class using conventional learning, it means that the CORE learning model influences student learning outcomes. 


\section{Discussion}

Mathematics learning outcomes of Grade VII students State Junior High School of 34 Pekanbaru before the research held are still relatively low. Learning activities that occur in the previous class more dominated by the teacher, namely lectures, debriefing and assignments. It has become one of the reasons why students are less active during the learning process. A Learning model is used by researchers as an alternative in the learning process when research is a CORE learning model.

The analysis used in this research is descriptive analysis and inferential analysis. Before the two classes given treatment, the first is held. Then proceed with the homogeneity test and data obtained are not homogeneous and continued with the T-test. From the analysis of the posttest data obtained, it can be seen that the average experimental class was 83.70, and the control class was 68.02. Based on the results of inferential statistical analysis, the posttest value is obtained that $t_{\text {count }}^{\prime}>t^{\prime}$ table so that $\mathrm{H}_{0}$ is rejected and $\mathrm{H}_{1}$ is accepted. It means that there is an influence of the CORE learning model on mathematics learning outcomes of Grade VII students of State Junior High School 34 Pekanbaru. The average scores of the pretest and posttest of the experimental and control classes can be seen in Figure 3. This expression is in line with research conducted by Chistella and Hadi [15] that there is a significant difference between the pre-test and post-test of the experimental group applied by using a model of CORE. The use of the model is a very supportive CORE learning system. As reported by [16] that the teaching model CORE more articulate what kind of teaching and practical learning in the public education system is transformed - a system that empowers students to take ownership of their learning, which emphasizes learning content and application of knowledge and skills to real-world problems, that respects differences carried by each learner to the learning experience, and who take advantage of learning environment is changing rapidly to recognize the possibility that they bring to maximize learning and engage learners. Besides, the model CORE assist students in exploring new understanding and organizing concept understanding he gained. This understanding can be affective and cognitive. In terms of the cognitive, the most crucial thing is the result of the learning process [17]. In the study described the form of learning outcomes with an emphasis on cognitive aspects as described in Figure 3.

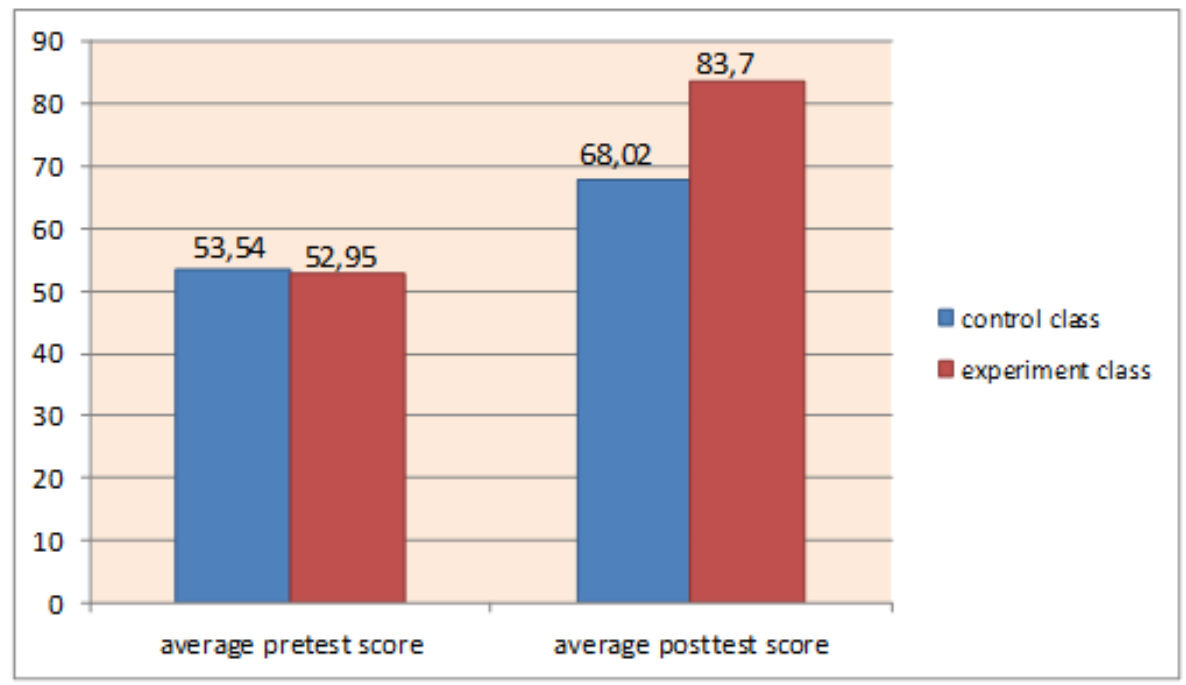

Figure 3. An average score of Pretest and Posttest scores 
Based on Figure 3, it can be seen the value in the experimental class, and the pretest value in the control class has the same ability based on the test difference of the two average pretest scores. After being given treatment, the average posttest learning outcomes of the experimental class are better than the average learning outcomes of the control class. Means that the use of the CORE learning model has a better effect than conventional learning models. In this line with research conducted by [18] that the model CORE better than students who use conventional learning. It is because the CORE model consists of several phases, namely the connecting phase makes students remember old information and relate it to new information. In the organizing phase, the activities undertaken are organizing ideas of the students to form an understanding of new concepts. The phase of reflection dramatically assists students in improving their mistake about the concept they get. Finally, the extension phase by doing exercises make students a better understanding of the concept.

It can be seen from the results of the experience gained during the learning of the CORE model in the experimental class, the learning activities of students in the class are an evident influence. Although at first, the students viewed as not active and they are still confused in working on the questions on the student activity sheet, which were distributed by each group member. However, at subsequent meetings, they have shown participation in discussing with the group and began to understand the use of the CORE model in the student worksheet. It is because the CORE model includes four phases are interrelated has integrated functions. Linking to CORE is used to train students' memories related to old information and use it to learn new concepts. Organizing activities help students organize ideas they already have to understand the next concepts. Reflection activity plays a role in inviting students to rethink the ideas they already have, explore, explore and strengthen the information they have acquired, and train them to describe the information that they have acquired. Then expand the activities as activities to develop and use the information that has been obtained by doing exercisesso that the concept they understand become more profound and more durable[19], [20]. Rebbecca [21] in the study reported that by applying the CORE learning in teaching can facilitate students in transferring the knowledge he acquired.

The CORE learning model provides opportunities for students to interact in their groups during the learning process. Where groups of 5-6 people have mixed abilities, students who have high abilities can help friends who are moderate and low ability in the learning process. Through discussion, there is communication and provides opportunities for students to express their ideas, and when they do not understand the subject matter, they ask questions with group friends or with the teacher. Then at the end of the discussion, the teacher questions the group who has finished working on the worksheets to present the results of their discussion in front of the class.

Meanwhile, based on observations of researchers in the control class applying conventional learning models, the teacher's role is more dominant than students. Students spend respects to the explanation given by the teacher and students take notes that are given by the teacher. Sometimes when the teacher explains in front of the class, students tend not to see and make noise, but some students are active to answer the questions given by the teacher, while others only listen to the answers given with their friends. It will have an impact on the lack of mathematics learning outcomes seen in the final results (Posttest).

Based on the results of data analysis and observation, the accepted research hypothesis is that there is a significant influence of the CORE learning model on mathematics learning outcomes of Grade VII students of Junior High School of 34 Pekanbaru.

\section{Conclusions}

The CORE model is instrumental to be able to connect understanding concepts and problem-solving. The CORE model has an essential role in constructing understanding and problem-solving both in groups or individually. From this study, the CORE model has a significant increase between the control class (VII-1) and the experimental class (Class VII-2) with a significant level of significance. Finally, from this study, it can be concluded that the CORE model influences mathematics learning outcomes, especially in the Cognitive Domain.

\section{Acknowledgements}

The author would like thank to Head Department of Mathematic Islamic University of Riau and Department of Educational Research and Evaluation State University Yogyakarta for support and assisted on researcher so the research can be completed. Then, We are very grateful to Chairman of State Junior High School of 34 Pekanbaru for all facilities and provided during the research process.

\section{REFERENCES}

[1] N. Hidayati and L. Roesdiana, "Meningkatkan kemampuan koneksi matematik mahasiswa melalui model pembelajaran CORE dengan metode diskusi [Improve students' mathematical connection skills through the CORE learning model with the discussion method]," Jurnal Penelitian Pendidikan dan Pengajaran Matematika, vol. 4, no. 1, pp. 31-34, 2019.

[2] L. Purwati, Rochmad, and Wuryanto, "An analysis of mathematical problem-solving ability based on hard work 
character in mathematics learning using connecting organizing reflecting extending model," Unnes Journal of Mathematics Education, vol. 7, no. 3, pp. 195-202, 2018.

[3] D. Fisher, P. Yuniawati, and Yaya Sukjaya Kusumah, "The use of CORE model by metacognitive skill approach in developing characters junior high school students," in The 4th International Conference on Research, Implementation, and Education of Mathematics and Science, 2017, vol. 050010, no. August, pp. 1-24.

[4] Fatmawati, L. Sukariasih, S. Fayanto, and Heri retnawati, "Investigating the Effectiveness of Inquiry Learning and Direct Learning Models toward Physics Learning," in 1st International Conference on Progressive Civil Society (IConProCS 2019) Investigating, 2019, vol. 317, no. IConProCS, pp. 260-265.

[5] S. Fayanto, D. Sulisworo, Misrawati, H. F. N. Istiqomah, and Luh Sukariasih, "The Implementation of Multimedia on Physics Learning Based on Direct Instruction Model in The Topic of Light," Indonesia Journal of Learning Education and Counseling, vol. 1, no. 2, pp. 124-132, 2019.

[6] M. D. Putri and R. Ro. M. Arifin, "Pengaruh penerapan model CORE (Connecting, Organizing, Reflecting, Extending) terhadap kemampuan berpikir kritis matematis siswa Sekolah Dasar [The effect of the application of the CORE model (Connecting, Organizing, Reflecting, Extending)," Antologi UPI, vol. 5, no. 1, pp. 111-123, 2017.

[7] R. L. Linto, S. Elniati, and Yusmet Rizal, "Kemampuan koneksi matematik dan metode pembelajaran quantum teaching dengan Peta pikiran [Mathematical Connection Capabilities and Quantum Teaching-Learning Methods with Mind Maps]," Jurnal Pendidikan Matematika, vol. 1, no. 1, pp. 83-87, 2012

[8] D. Safitri, S. Handayani, and N. Umamah, "Penerapan Model Connecting , Organizing , Reflecting , dan Extending ( CORE ) Untuk meningkatkan kreativitas dan Hasil belajar Sejarah peserta didik kelas X3 SMAN 1 Bangorejo Tahun Ajaran 2013 / 2014 [The application of Model Connecting, Organizing, Ref," JURNAL EDUKASI UNEJ, vol. 1, no. 2, pp. 10-14, 2014.

[9] M. S. Curwen, R. G. Miller, K. A. White-Smith, and Robert C. Calfee, "Increasing teachers ' metacognition develop students ' higher learning during content area literacy instruction: findings from the read-write cycle project," Issues in Teacher Education, vol. 19, no. 2, pp. 127-151, 2010.

[10] S. U. S, A. Asmar, and B. Oktavia, "Learning tools based on connecting, organizing, reflecting and extending (Core) models for class viii small classes Valid," in 2nd International Conference on Mathematics and Mathematics Education 2018, 2018, vol. 285, no. Icm2e, pp. 246-249.

[11] I. Y. Arizal, E. Musdi, and S. Ramadhan, "The influence of learning device with core model to improve the problem-solving ability of student class VIII of junior high school," in 2nd International Conference on Mathematics and Mathematics Education 2018 (ICM2E 2018) The, 2018, vol. 285, no. Icm2e, pp. 343-345.

[12] A. R. Yulianto and N. K. Dwidayati, "The Effectiveness of core models with scaffolding to improve the mathematical connection skill," vol. 9, no. 1, pp. 1-7, 2020.
[13] Ngurah Jaya Wicaksana, I. N. Wirya, and I. G. Marhunayasa, "Pengaruh model pembelajaran Core (Connecting Organizing Reflecting Extending) berbasis koneksi matematis terhadap hasil belajar matematika [The influence of core learning model (connecting organizing reflecting extending) based on mathematical connection]," e-Journal Mimbar PGSD Universitas Pendidikan Ganesha, vol. 2, no. 1, pp. 1-10, 2014.

[14] R. Avanti, Suyatno, and B Sugiarto, "The development of learning materials based on core model to improve students ' learning outcomes in the topic of Chemical Bonding The development of learning materials based on core model to improve students ' learning outcomes in the topic of Chemical Bonding," IOP Conf. Series: Journal of Physics: Conf. Series, vol. 012012, no. 1006, pp. 1-8, 2018.

[15] C. Chistella and H. Soekamto, "A Comparison between generative learning model and CORE learning model: the influence on learners' higher-order thinking skill,' IOSR Journal of Research \& Method in Education (IOSRJRME), vol. 07 , no. 02, pp. 48-52, Feb. 2017.

[16] Assessment, Interstate Teacher, and Support Consortium. "Model core teaching standards and learning progressions for teachers." (2013).

[17] E. Yerushalmi, C. Henderson, K. Heller, P. Heller, and V. Kuo, "Physics faculty beliefs and values about the teaching and learning of problem-solving. I. Mapping the common core," Physical Review Special Topics - Physics Education Research, vol. 3, no. 2, Dec. 2007

[18] Yarman, A. Fauzan, Lufri, and Armiati, "Application of connecting learning model-organizing-reflecting-extending on the ordinary differential equations course," Proceedings of the 2nd International Conference on Mathematics and Mathematics Education 2018 (ICM2E 2018), 2018.

[19] B. S. Bell and S. W. J. Kozlowski, “Active learning: Effects of core training design elements on self-regulatory processes, learning, and adaptability.," Journal of Applied Psychology, vol. 93, no. 2, pp. 296-316, 2008.

[20] C. S. E. Homer, M. Griffiths, P. M. Brodie, S. Kildea, A. M. Curtin, and D. A. Ellwood, "Developing a core competency model and educational framework for primary maternity services: a national consensus approach," Women and Birth, vol. 25, no. 3, pp. 122-127, Sep. 2012.

[21] R. J. Romsdahl and M. J. Hill, “Applying the learning community model to graduate education: linking research and teaching between core courses," Teaching in Higher Education, vol. 17, no. 6, pp. 722-734, Dec. 2012. 